\title{
ANALISIS INFORMASI ANATOMI DENGAN DAN TANPA PARALLEL ACQUISITION TECHNIQUE MENGGUNAKAN SEKUEN 2D THICK SLAB SINGLE SHOT FAST SPIN ECHO PADA PEMERIKSAAN MAGNETIC RESONANCE CHOLANGIOPANCREATOGRAPHY (MRCP)
}

\section{ANALYSIS OF ANATOMICAL INFORMATION WITH AND WITHOUT PARALLEL ACQUISITION TECHNIQUE USING 2D THICK SLAB SINGLE SHOT FAST SPIN ECHO SEQUENCE ON MAGNETIC RESONANCE CHOLANGIOPANCREATOGRAPHY (MRCP) EXAMINATION}

\author{
Rismawati Dian Aretnasih ${ }^{1)}$, Lydia Purna WSK ${ }^{2)}$, Siti Masrochah ${ }^{3)}$ \\ ${ }^{1,3)}$ Health Polytechnics of Semarang-Indonesia \\ ${ }^{2)}$ Physician in National Diponegoro Hospital, Semarang \\ e-mail: dianaretnasih@gmail.com
}

\begin{abstract}
Backgroud: 2D thick slab single shot fast spin echo (SSFSE) sequence in MRCP examination is a sequence of fast spin echo (FSE) which has a long turbo factor so that the time of acquisition in this sequence is longer than usual that will potentially cause image blurring. Parallel acquisition or SENSE technique is a technique used to reduce acquisition time and improve spatial resolution. The purpose of this study was to determine differences in anatomical information with and without parallel acquisition technique in 2D thick slab SSFSE sequences on MRCP examination.

Methods: This research was an experimental study. This research was conducted by Philips 1.5 T MRI unit in dr. S Hardjolukito Yogyakarta Hospital. Data were 20 MRCP images from 10 normal volunteers with and without parallel acquisition technique on sequences of $2 \mathrm{D}$ thick slab SSFSE. Assessment of the images was conducted qualitatively in the form of respondents's assessment of the clearance of anatomical information includes the gallbladder, right hepatic duct, left hepatic duct, common bile duct, common hepatic duct, cystic duct, and the main pancreatic duct. Quantitative data analyzed by Cohen's Kappa test, cross tabulation, and Wilcoxon tests.

Results: The result showed that there was a difference between the clearance of the overall anatomical information between $2 \mathrm{D}$ thick slab SSFSE sequences with and without parallel acquisition technique in MRCP with $p=0.000$ ( $p$-value $<0.05$ ), based on the mean rank obtained sequences of 2D thick slab SSFSE SENSE (14.50) better than the 2D thick slab SSFSE (0.00). Analysis of each anatomy showed significant differences in all organs except the gallbladder $\mathrm{p}=0.059, \mathrm{p}=$ left hepatic duct and the common bile duct 0.059 with $\mathrm{p}=0.08$.

Conclusion: Parallel acquisition technique (SENSE) was well used because it has a faster acquisition time without decreasing image resolution.
\end{abstract}

Keywords : parallel acquisition technique, 2D thick slab SSFSE, sensitivity encoding, pancreatobiliary tree, MRCP

\section{PENDAHULUAN}

Magnetic Resonance Cholangio Pancreatography (MRCP) merupakan pemeriksaan untuk melihat ductus biliary, ductus hepatica dan ductus pancreaticus. Biasanya MRCP menggunakan protokol dengan sekuen T2W, diakuisisi baik dengan thin slice selection atau thick slab atau keduanya (Mandarano, 2008). MRCP biasanya menggunakan sekuen T2 weighted dengan fast spin echo atau single shot fast spin echo dan menggunakan kolimasi tebal (single section) dan kolimasi tipis (multisection) dengan torso phased array coil. Selain itu, beberapa institusi menggunakan rekontruksi 3D dengan menggunakan algorithma maximum intensity projection (MIP) pada kolimasi tipis. Meskipun kolimasi tebal dan 3D MIP mirip dengan cholangiogram konvensional dan familiar untuk semua klinisi, spatial resolution menurun karena efek volume averaging (Kenneth, 2000).

Sekuen yang digunakan pada pemeriksaan MRCP adalah sekuen thick slab single shot fast spin echo. Thick slab single shot fast spin echo merupakan sekuen fast spin echo (FSE) atau turbo spin echo (TSE) yang berdasar pada potongan 2D single shot pada satu slice dengan slice thickness tebal (30-80 $\mathrm{mm})$ yang diperoleh dari beberapa bidang. Sekuen ini menggunakan pulsa RF $90^{\circ}$ diikuti dengan ETL panjang, seperti contoh 256 spin echo atau lebih. Semua data diperoleh setelah eksitasi pulsa RF tunggal dalan satu echo train tunggal, setiap spin echo tunggal terpisah dengan phase encoding (Manfredi, 2013).

Sekuen 2D Single shot fast spin echo (SSFSE) pada pemeriksaan MRCP merupakan sekuen yang lebih cepat dibandingkan dengan sekuen MRCP yang dapat dilakukan dengan breath hold, yang mengurangi motion artifact dan meningkatkan kualitas citra. Sebagai hasil dari pengurangan motion artifact (noise) dengan single shot fast spin echo $\mathrm{MRCP}$, signal to noise ratio (SNR) meningkat jika digabungkan dengan fast spin echo. Selain itu terjadi 
penurunan sinyal meskipun tidak sebesar penurunan noise, hasilnya adalah penurunan spatial resolution. Kecepatan akuisisi tergantung pada ETL, TR yang tidak terhingga, dan kemapuan rekonstruksi citra setelah memperoleh setengah dari phase encoding steps. Teknik breath hold digunakan untuk mengurangi artefak dari respiratory motion (Kenneth, 2000).

Parallel imaging merupakan teknik pengurangan waktu yang menggunakan phased array coil. Phased array coil mengukur dan memproses sinyal dari sebuah potongan, kemudian menggabungkan potongan untuk membentuk gambar yang area yang lebih besar dari anatomi. Teknik akuisisi paralel memperoleh bagian dari $K$-Space dengan setiap koil elemen, kemudian menggabungkannya untuk membentuk gambar akhir. Waktu scan menjadi berkurang karena berkurangnya jumlah baris yang diperoleh untuk setiap elemen. Jumlah elemen yang digunakan dalam pengukuran adalah proporsional dengan pengurangan waktu scan (Brown dan Semelka, 2015).

Pada saat parallel imaging diaplikasikan pada sekuen 2D thick slab SSFSE. Penurunan jumlah phase encoding step dapat menyebabkan penurunan echo train lenght (ETL), menghasilkan readout pendek dengan sedikit $\mathrm{T} 2$ related signal decay dan memperbaiki detail gambar dengan mengurangi image blur. Reduksi image blur dapat diartikan sebagai edge enhancment yang dapat memperbaiki gambaran pertengahan dan tepi duktus pancreatobiliary (Griswold, 1999).

Parallel imaging memanfaatkan sensitifitas informasi spasial dari element multiple independent receceiver coil untuk mengurangi jumlah phase encoding steps, oleh karena itu waktu scanning berkurang. Parallel imaging dapat digunakan dalam pemeriksaan dengan breath hold dan menghasilkan TE efektif yang lebih pendek dan mengurangi blurring pada sekuen echo train seperti Single Shot Fast Spin Echo (SSFSE). Teknik 2D parallel imaging menyediakan acceleration factor yang lebih tinggi dengan mengurangi jumlah ukuran yang diperlukan untuk mengisi $k$-space pada kedua fase dan arah partisi (Leyendecker, 2015)

Pada pemeriksaan MRCP khususnya pada sekuen 2D Thick Slab Single Shot Fast Spin Echo (SSFSE) memiliki kelemahan yaitu penurunan spatial resolution yang akan menggangu kejelasan informasi anatomi. Untuk meningkatkan spatial resolution diperlukan suatu teknik yaitu sensitivity encoding atau SENSE. Selain meningkatkan spatial resolution, SENSE berfungsi untuk mengurangi waktu akuisisI dan menigkatkan jumlah slice sehingga dapat mencegah terjadinya misregistration informasi anatomi. Fast imaging merupakan fungsi dari teknik SENSE. Reduksi scan time dapat meningkatkan kualitas citra karena respiratory motion atau peristaltik usus. Selain mereduksi scan time, SENSE dapat memperbaiki spatial resolution dan meningkatkan jumlah slice (Kurihara, 2002).

Berdasarkan pengamatan penulis, penulis mendapatkan bahwa dalam pelaksanaan pemeriksaan MRCP sekuen 2D thick slab SSFSE sering digunakan dibandingkan sekuen 3D FRFSE. Pada sekuen 2D Thick Slab Single Shot Fast Spin
Echo (SSFSE) menggunakan teknik breath hold dengan waktu tahan nafas yang panjang (8 detik) dan belum menerapkan teknik sensitivity encoding (SENSE). Dengan pengaplikasisn parallel acquisition technique atau sensitivity encoding (SENSE) pada sekuen tersebut, apakah dapat menurunkan waktu akuisisi tanpa menurunkan kualitas citra terutama informasi anatomi.

\section{METODE}

Penelitian ini merupakan penelitian kuantitatif dengan pendekatan eksperimen. Penelitian ini dilakukan pada bulan April hingga Juni 2016 di Inslatasi Radiologi RSPAU Dr. S. Hardjolukito Yogyakarta. Populasi penelitian ini adalah semua pemeriksaan MRCP pada ulan April hingga Juni 2016. Sampel dalam penelitian ini terdiri dari 10 volunteer normal dengan kriteria inklusi berusia 20 hingga 30 tahun dan kriteria eksklusi pada volunteer yang memiliki riwayat klinis pada sistem biliary serta claustrophobia.

Penelitian dilakukan pada sepuluh (10) volunteer normal. Masing-masing pasien dilakukan scanning MRCP irisan coronal oblique menggunakan SENSE Body Coil dengan protokol yang telah ditentukan yaitu sekuen 2D SSFSE tanpa aplikasi parallel acquisition technique yang disebut juga dengan sensitivity encoding (SENSE) (TR 8000; TE 800; flip angle $90^{\circ}$; turbo factor 256 ; matrix $512 \times 512$; FOV 300x300 mm; slice thickness 40mm; jumlah slice 9; radial angle $20^{\circ}$ dan waktu akuisis 72 detik). Kemudian dilanjutkan dengan scanning pada sekuen yang sama dengan aplikasi parallel acquisition technique (SENSE) (TR 4000; TE 800; flip angle $90^{\circ}$; turbo factor 127 ; matrix $512 \times 512$; FOV 300x300 mm; slice thickness 40mm; jumlah slice 9; radial angle $20^{\circ}$; reduction factor 2 dan waktu akuisis 72 detik).

Data hasil kuisioner yang diperoleh dari hasil ekspertisi dua dokter spesialis radiologi terhadap 10 citra pada sekuen 2D Thick Slab Single Shot Fast Spin Echo (SSFSE) dengan dan tanpa aplikasi parallel acquisition technique yang dicetak dalam 1 film. Data yang dihasilkan berupa data ordinal dari hasil jawaban kuisioner yang diberikan dokter spesialis radiologi mengenai kejelasan informasi anatomi. Hasil penilaian kedua dokter spesialis radiologi dilakukan uji Cohen's Kappa untuk mengetahui tingkat obyektifitas dari penilaian kedua responden terhadap kedua teknik tersebut. Selanjutnya data dianalisa dengan uji tabulasi silang (crosstabulation) untuk mengetahui persentase penilaian kejelasan informasi anatomi citra dari responden dan uji Cohen's Kappa untuk. Kemudian dilakukan uji wilcoxon untuk mengetahui perbedaan kejelasan informasi anatomi terhadap kedua teknik tersebut. Penialian didasarkan pada teori Sugiyono (2004), jika p-value lebih kecil atau sama dengan 0,05 maka Ha diterima dan Ho ditolak.

\section{HASIL \\ Karakteristik Sampel}

Tabel 1 menunjukkan karakteristik sampel berdasarkan jenis kelamin dapat diketahui bahwa dalam penelitian ini menggunakan 10 sampel yang terdiri dari 7 (70\%) sampel 
laki-laki dan 3 (30\%) sampel perempuan. Berdasarkan umur dapat diketahui bahwa dalam penelitian ini menggunakan 10 sampel yang terdiri dari $9(90 \%)$ sampel berusia antara 20 hingga 25 tahun dan 1 (10\%) sampel berusia antara 26 hingga 30 tahun.

Tabel 1. Deskripsi Sampel Berdasarkan Jenis Kelamin dan Umur

\begin{tabular}{cccc}
\hline No & Volunteer & Jenis Kelamin & Umur \\
\hline 1 & A & Perempuan & 21 \\
\hline 2 & B & Laki-laki & 21 \\
\hline 3 & C & Laki-laki & 27 \\
\hline 4 & D & Laki-laki & 23 \\
\hline 5 & E & Laki-laki & 23 \\
\hline 6 & F & Laki-laki & 21 \\
\hline 7 & G & Perempuan & 22 \\
\hline 8 & H & Laki-laki & 21 \\
\hline 9 & I & Perempuan & 20 \\
\hline 10 & J & Laki-laki & 21 \\
\hline
\end{tabular}

Hasil Uji Responden Terhadap Informasi Anatomi Antara Sekuen 2D Thick Slab Single Shot Fast Spin Echo dengan dan tanpa Parallel Acquisition Technique Pada Pemeriksaan MRCP.

Data diperoleh dari hasil penilaian citra dengan memberikan skor 1, 2 atau 3 pada setiap citra yang dihasilkan pada sekuen 2D thick slab SSFSE dengan dan tanpa aplikasi parallel acquisition technique atau sensitivity encoding (SENSE). Kemudian nilai skor masing-masing citra dari kedua responden dirangkum dan dianalisa menggunakan uji Cohen's Kappa. Uji Cohen's Kappa digunakan untuk mengukur tinggat kesepakatan (degree of agreement) dari kedua responden dalam menilai kedua teknik tersebut. Berdasarkan analisis menggunakan SPSS 16, dengan uji Cohen's Kappa hasil penilaian kedua responden terhadap informasi anatomi antara sekuen dengan dan tanpa aplikasi SENSE sebagai berikut :

Tabel 2. Hasil Uji Statistik Kappa Kedua Responden Antara Citra Sekuen 2D Thick Slab SSFSE Dengan SENSE dan Tanpa SENSE

\begin{tabular}{ccc}
\hline Teknik & $\begin{array}{c}\text { Koefisien } \\
\text { Kappa }\end{array}$ & $\begin{array}{c}\text { Jumlah } \\
\text { Sampel }\end{array}$ \\
\hline 2D Thick Slab SSFSE & 0,732 & 10 \\
\hline 2D Thick Slab SSFSE SENSE & 0,688 & 10 \\
\hline
\end{tabular}

Dari hasil analisa uji Cohen's Kappa diatas, dari kedua responden diperoleh degree of agreement pada sekuen 2D thick slab SSFSE sebesar 0,732 dan pada sekuen 2D thick slab SSFSE SENSE sebesar 0,688. Hasil uji kappa yang diperoleh menunjukkan tingkat kesepakatan yang baik karena berada pada rentang 0,61 hingga 0,80 .

Hasil Uji Beda Informasi Anatomi Keseluruhan Antara Sekuen 2D Thick Slab Single Shot Fast Spin Echo (SSFSE) dengan dan tanpa Parallel Acquisition Technique Pada Pemeriksaan MRCP

Uji beda informasi anatomi secara keseluruhan yang digunakan dalam penilaian sekuen 2D thick slab SSFSE dengan dan tanpa SENSE pada pemeriksaan MRCP adalah uji tabulasi silang (crosstabulation) dan uji wilcoxon. Uji tabulasi silang digunakan untuk melihat persentase penilaian citra dari responden. Uji wilcoxon digunakan karena data berbentuk ordinal dan berdistribusi tidak normal. Perbedaan diukur dari p-value, jika p-value kurang dari 0,05 menunjukkan adanya perbedaan antara sekuen 2D thick slab SSFSE dengan SENSE dan sekuen 2D thick slab SSFSE tanpa SENSE. Kejelasan informasi anatomi yang lebih baik dinilai dari mean rank.

Berdasarkan hasil uji tabulasi silang untuk melihat persentase penilaian responden terhadap kejelasan informasi anatomi citra sekuen 2D thick slab SSFSE dan 2D thick slab SSFSE SENSE diperoleh hasil sebagai berikut :

Tabel 3. Hasil Penilaian Reponden Terhadap Citra Sekuen 2D Thick Slab SSFSE dan 2D Thick Slab SSFSE SENSE Pada Keseluruhan Informasi Anatomi

\begin{tabular}{ccccc}
\hline \multirow{2}{*}{ Citra } & \multicolumn{3}{c}{ Skor } & Total \\
\cline { 2 - 4 } & $\begin{array}{c}\text { Tidak } \\
\text { Terlihat }\end{array}$ & $\begin{array}{c}\text { Tidak } \\
\text { Jelas }\end{array}$ & Jelas & \\
\hline $\begin{array}{c}\text { 2D Thick Slab } \\
\text { SSFSE }\end{array}$ & $10 \%$ & $28,6 \%$ & $11,4 \%$ & $50 \%$ \\
\hline $\begin{array}{c}\text { 2D Thick Slab } \\
\text { SSFSE SENSE }\end{array}$ & $2,9 \%$ & $20,7 \%$ & $26,4 \%$ & $50 \%$ \\
\hline Total & $12,9 \%$ & $49,3 \%$ & $37,9 \%$ & $100 \%$ \\
\hline
\end{tabular}

Tabel 3 menunjukkan bahwa dari hasil uji tabulasi silang terhadap kejelasan informasi anatomi antara citra sekuen 2D thick slab SSFSE dan 2D thick slab SSFSE SENSE, diperoleh persentase penilaian citra yaitu jawaban responden "tidak terlihat" (2D thick slab SSFSE $=10 \%$, 2D thick slab SSFSE SENSE $=2,9 \%$ ), jawaban responden "tidak jelas" (2D thick slab SSFSE $=28,6 \%, 2 \mathrm{D}$ SSFSE thick slab SENSE $=20,7 \%$ ), dan jawaban responden "jelas" (2D thick slab SSFSE = $11,4 \%, 2 \mathrm{D}$ thick slab SSFSE SENSE $=26,4 \%$ ).

Uji wilcoxon pada perbandingan informasi anatomi secara keseluruhan antara menggunakan SENSE dan tanpa menggunakan SENSE pada pemeriksaan MRCP diperoleh hasil sebagai berikut :

Tabel 4. Hasil Uji Wilcoxon Informasi Citra Anatomi Keseluruhan antara sekuen 2D Thick Slab SSFSE dan 2D Thick Slab SSFSE SENSE

\begin{tabular}{ccc}
\hline Teknik & $\begin{array}{c}\text { Mean } \\
\text { Rank }\end{array}$ & $\boldsymbol{p}$-value \\
2D thick slab SSFSE & 0,00 & \multirow{2}{*}{0,000} \\
\cline { 1 - 1 } 2D thick slab SSFSE SENSE & 14,50 &
\end{tabular}

Berdasarkan hasil uji Wilcoxon diperoleh $p$-value sebesar $0,000(\mathrm{p}<0,05)$. Dari nilai tersebut dapat diketahui bahwa terdapat perbedaan yang bermakna informasi anatomi secara keseluruhan antara menggunakan teknik SENSE dan tidak menggunakan teknik SENSE pada pemeriksaan MRCP dengan menggunakan sekuen 2D thick slab SSFSE. 
Berdasarkan nilai mean rank secara keseluruhan, sekuen 2D thick slab SSFSE dengan SENSE pada pemeriksaan MRCP menghasilkan informasi anatomi yang lebih baik dibandingkan dengan sekuen 2D thick slab SSFSE tanpa menggunakan SENSE dengan nilai mean rank 14,50.

Hasil Uji Beda Informasi Anatomi Setiap Bagian Antara Sekuen 2D Single Shot Fast Spin Echo Dengan dan Tanpa Parallel Acquisition Technique Pada Pemeriksaan MRCP

Hasil penilaian informasi anatomi dari setiap masingmasing bagian organ sistem biliary meliputi gall bladder (GB), right hepatic duct (RHD), left hepatic duct (LHD), common bile duct (CBD), common hepatic duct (CHD), cystic duct (CD) dan main pancreatic duct (MPD) dianalisa dengan menggunakan Uji Wilcoxon untuk mengetahui perbedaan informasi citra anatomi antara sekuen 2D thick slab SSFSE tanpa SENSE dan sekuen 2D thick slab SSFSE dengan SENSE. Berikut merupakan hasil analisa uji tersebut :

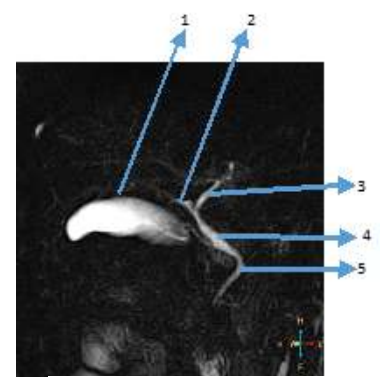

Keterangan gambar :

1. Gall Bladder

2. Right Hepatic Duct

3. Left Hepatic Duct

4. Common Hepatic Duct

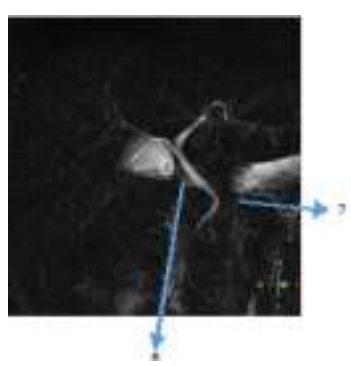

5. Gall Bladder

6. Cystic Duct

7. Main Pancrestic Duct

Gambar 1. Citra Sekuen 2D Thick Slab Single Shot Fast Spin Echo (SSFSE) Tanpa Aplikasi SENSE

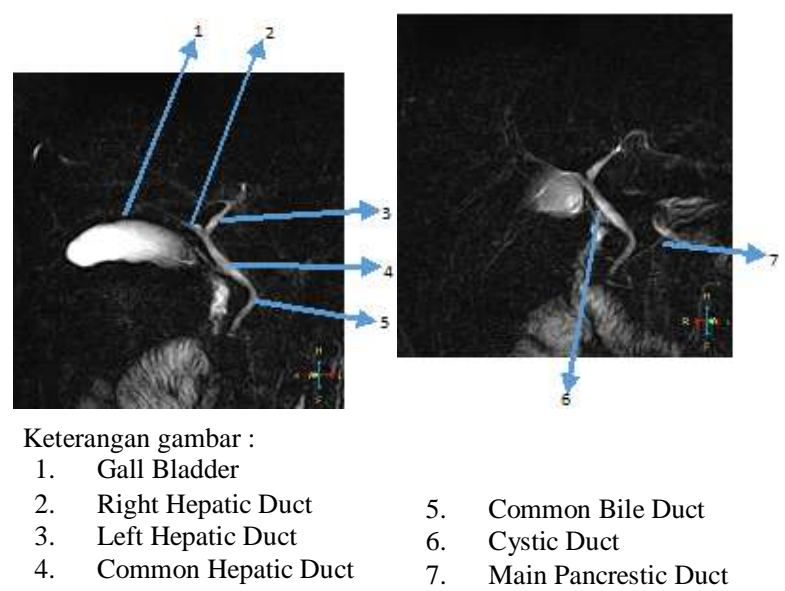

Gambar 2. Citra Sekuen 2D Thick Slab Single Shot Fast Spin Echo (SSFSE) Dengan Aplikasi SENSE

Berdasarkan tabel 5 dan tabel 6, diperoleh beberapa anatomi yang memimiliki perbedaan antara lain right hepatic duct, common hepatic duct, cystic duct dan main pancreatic duct. Sedangkan anatomi yang tidak memiliki perbedaan terdiri dari gall bladder, left hepatic duct dan common bile duct.
Tabel 5. Hasil Penilaian Responden Terhadap 10 Citra Sekuen 2D Thick Slab SSFSE dan Sekuen 2D Thick Slab SSFSE SENSE Pada Kejelalasan Informasi Masing-masing Anatomi

\begin{tabular}{|c|c|c|c|c|c|}
\hline No & $\begin{array}{l}\text { Anatomi } \\
\text { Citra }\end{array}$ & Sekuen & $\begin{array}{c}\text { Tidak } \\
\text { Terlihat }\end{array}$ & $\begin{array}{c}\text { Tidak } \\
\text { Jelas }\end{array}$ & Jelas \\
\hline \multirow{2}{*}{1} & \multirow{2}{*}{ GB } & $\begin{array}{c}\text { 2D Thick Slab } \\
\text { SSFSE }\end{array}$ & $15 \%$ & $20 \%$ & $15 \%$ \\
\hline & & $\begin{array}{l}\text { 2D Thick Slab } \\
\text { SSFSE SENSE }\end{array}$ & $5 \%$ & $15 \%$ & $30 \%$ \\
\hline \multirow{2}{*}{2} & \multirow{2}{*}{ RHD } & $\begin{array}{c}\text { 2D Thick Slab } \\
\text { SSFSE }\end{array}$ & $0 \%$ & $45 \%$ & $5 \%$ \\
\hline & & $\begin{array}{l}\text { 2D Thick Slab } \\
\text { SSFSE SENSE }\end{array}$ & $0 \%$ & $25 \%$ & $25 \%$ \\
\hline \multirow{2}{*}{3} & \multirow{2}{*}{ LHD } & $\begin{array}{c}\text { 2D Thick Slab } \\
\text { SSFSE }\end{array}$ & $10 \%$ & $35 \%$ & $5 \%$ \\
\hline & & $\begin{array}{l}\text { 2D Thick Slab } \\
\text { SSFSE SENSE }\end{array}$ & $5 \%$ & $20 \%$ & $25 \%$ \\
\hline \multirow{2}{*}{4} & \multirow{2}{*}{ CBD } & $\begin{array}{l}\text { 2D Thick Slab } \\
\text { SSFSE }\end{array}$ & $15 \%$ & $20 \%$ & $15 \%$ \\
\hline & & $\begin{array}{l}\text { 2D Thick Slab } \\
\text { SSFSE SENSE }\end{array}$ & $5 \%$ & $25 \%$ & $20 \%$ \\
\hline \multirow{2}{*}{5} & \multirow{2}{*}{ CHD } & $\begin{array}{c}\text { 2D Thick Slab } \\
\text { SSFSE }\end{array}$ & $0 \%$ & $35 \%$ & $15 \%$ \\
\hline & & $\begin{array}{l}\text { 2D Thick Slab } \\
\text { SSFSE SENSE }\end{array}$ & $0 \%$ & $15 \%$ & $35 \%$ \\
\hline \multirow{2}{*}{6} & \multirow{2}{*}{$\mathrm{CD}$} & $\begin{array}{c}\text { 2D Thick Slab } \\
\text { SSFSE }\end{array}$ & $5 \%$ & $35 \%$ & $10 \%$ \\
\hline & & $\begin{array}{l}\text { 2D Thick Slab } \\
\text { SSFSE SENSE }\end{array}$ & $0 \%$ & $60 \%$ & $35 \%$ \\
\hline \multirow{2}{*}{7} & \multirow{2}{*}{ MPD } & $\begin{array}{c}\text { 2D Thick Slab } \\
\text { SSFSE }\end{array}$ & $25 \%$ & $10 \%$ & $15 \%$ \\
\hline & & $\begin{array}{l}\text { 2D Thick Slab } \\
\text { SSFSE SENSE }\end{array}$ & $5 \%$ & $20 \%$ & $25 \%$ \\
\hline
\end{tabular}

GB : gall bladder, RHD : right hepatic duct, $L H D$ : left hepatic duct, $C B D$ : common bile duct, CHD : common hepatic duct, $C D$ : cystic duct, MPD : main pancreatic duct

Tabel 6. Hasil Uji Wilcoxon Informasi Anatomi Setiap Bagian pada sekuen 2D thick slab SSFSE dan 2D thick slab SSFSE SENSE

\begin{tabular}{cccc}
\hline No & Anatomi & $\boldsymbol{p}$-value & \\
\hline 1 & GB & 0,059 & Tidak Bermakna \\
2 & RHD & 0,046 & Bermakna \\
3 & LHD & 0,059 & Tidak Bermakna \\
4 & CBD & 0,083 & Tidak Bermakna \\
5 & CHD & 0,046 & Bermakna \\
6 & CD & 0,046 & Bermakna \\
7 & MPD & 0,034 & Bermakna
\end{tabular}

$G \bar{B}:$ gall bladder, $R H D$ : right hepatic duct, $L H D$ : left hepatic duct, $C B D$. common bile duct, CHD : common hepatic duct, CD : cystic duct, MPD : main pancreatic duct

Informasi Anatomi Yang Lebih Baik Antara Sekuen 2D Thick Slab Single Shot Fast Spin Echo dengan dan tanpa Parallel Acquisition Technique Pada Pemeriksaan MRCP

Perbandingan informasi anatomi pada sekuen 2D thick slab single shot fast spin echo (SSFSE) dengan dan tanpa aplikasi parallel acquisition technique atau disebut dengan sensitivity encoding (SENSE) pada pesawat MRI Philips 1,5 T dianalisa menggunakan nilai mean rank pada uji wilcoxon 
untuk mengetahui informasi anatomi yang lebih baik dari kedua teknik tersebut. Berdasarkan nilai mean rank dari setiap anatomi antara sekuen 2D thick slab SSFSE dengan dan tanpa SENSE diperoleh sebagai berikut :

Tabel 7. Hasil Mean Rank Uji Wilcoxon Antara Sekuen 2D thick $s l a b$ SSFSE (Non SENSE) dan 2D thick slab SSFSE SENSE Pada Pemeriksaan MRCP

\begin{tabular}{ccc}
\hline $\begin{array}{c}\text { Anatomi } \\
\text { Citra }\end{array}$ & Sekuen & Mean Rank \\
\hline \multirow{2}{*}{ GB } & NON SENSE & 0,00 \\
\cline { 2 - 3 } & SENSE & 2,50 \\
\hline \multirow{2}{*}{ RHD } & NON SENSE & 0,00 \\
\cline { 2 - 3 } & SENSE & 2,00 \\
\cline { 2 - 3 } LHD & NON SENSE & 0,00 \\
\cline { 2 - 3 } & SENSE & 2,50 \\
\cline { 2 - 3 } CBD & NON SENSE & 0,00 \\
\cline { 2 - 3 } CHD & SENSE & 2,50 \\
\cline { 2 - 3 } & NON SENSE & 0,00 \\
\hline \multirow{2}{*}{ CD } & SENSE & 2,50 \\
\cline { 2 - 3 } & NON SENSE & 0,00 \\
\hline \multirow{2}{*}{ MPD } & SENSE & 2,50 \\
\cline { 2 - 3 } & NON SENSE & 3,00 \\
\hline
\end{tabular}

$\overline{G B}$ : gall bladder, $R H D$ : right hepatic duct, $L H D$ : left hepatic duct, $C B D$ common bile duct, CHD : common hepatic duct, $C D$ : cystic duct, MPD : main pancreatic duct

Berdasarkan hasil meank rank uji wilcoxon diatas dari tujuh kriteria anatomi pada sekuen 2D thick slab single shot fast spin echo (SSFSE) antara menggunakan aplikasi SENSE dan tanpa aplikasi SENSE dapat diketahui bahwa mean rank informasi anatomi gall bladder pada sekuen 2D thick slab SSFSE yaitu 0,00 dan 2D SSFSE thick slab SENSE yaitu 2,50. Berdasarkan nilai mean rank tersebut, sekuen 2D thick slab SSFSE dengan SENSE menghasilkan informasi anatomi yang lebih baik dibandingkan tanpa SENSE pada pemeriksaan MRCP.

Hasil mean rank uji wilcoxon informasi anatomi right hepatic duct pada sekuen 2D thick slab SSFSE yaitu 0,00 dan 2D thick slab SSFSE SENSE yaitu 2,00. Berdasarkan nilai mean rank tersebut, sekuen 2D thick slab SSFSE dengan SENSE menghasilkan informasi anatomi yang lebih baik dibandingkan tanpa SENSE pada pemeriksaan MRCP.

Hasil mean rank uji wilcoxon informasi anatomi left hepatic duct pada sekuen 2D thick slab SSFSE yaitu 0,00 dan 2D thick slab SSFSE SENSE yaitu 2,50. Berdasarkan nilai mean rank tersebut, sekuen 2D thick slab SSFSE dengan SENSE menghasilkan informasi anatomi yang lebih baik dibandingkan tanpa SENSE pada pemeriksaan MRCP.

Hasil mean rank uji wilcoxon informasi anatomi common bile duct pada sekuen 2D thick slab SSFSE yaitu 0,00 dan 2D thick slab SSFSE SENSE yaitu 2,50. Berdasarkan nilai mean rank tersebut, sekuen 2D thick slab
SSFSE dengan SENSE menghasilkan informasi anatomi yang lebih baik dibandingkan tanpa SENSE pada pemeriksaan MRCP.

Hasil mean rank uji wilcoxon informasi anatomi common hepatic duct pada sekuen 2D thick slab SSFSE yaitu 0,00 dan 2D thick slab SSFSE SENSE yaitu 2,50. Berdasarkan nilai mean rank tersebut, sekuen 2D thick slab SSFSE dengan SENSE menghasilkan informasi anatomi yang lebih baik dibandingkan tanpa SENSE pada pemeriksaan MRCP.

Hasil mean rank uji wilcoxon informasi anatomi cystic duct pada sekuen 2D thick slab SSFSE yaitu 0,00 dan 2D thick slab SSFSE SENSE yaitu 2,50. Berdasarkan nilai mean rank tersebut, sekuen 2D thick slab SSFSE dengan SENSE menghasilkan informasi anatomi yang lebih baik dibandingkan tanpa SENSE pada pemeriksaan MRCP.

Hasil mean rank uji wilcoxon informasi anatomi main pancreatic duct pada sekuen 2D thick slab SSFSE yaitu 0,00 dan 2D thick slab SSFSE SENSE yaitu 3,00. Berdasarkan nilai mean rank tersebut, sekuen 2D thick slab SSFSE dengan SENSE menghasilkan informasi anatomi yang lebih baik dibandingkan tanpa SENSE pada pemeriksaan MRCP.

\section{DISKUSI}

Magnetic Resonance Cholangio Pancreatography (MRCP) merupakan pemeriksaan untuk melihat ductus biliary, ductus hepatica dan ductus pancreaticus. Biasanya MRCP menggunakan protokol dengan sekuen T2W, diakuisisi baik dengan thin slice selection atau thick slab atau keduanya (Mandarano, 2008). Pemeriksaan MRCP merupakan pemeriksaan pada organ bergerak (organ biliary), maka pada pemeriksaan ini dibutuhkan waktu yang singkat untuk menghasilkan citra yang optimal.

Pada penelitian tentang MRCP ini digunakan sekuen 2D thick slab single shot fast spin echo (SSFSE) yang dalam pesawat MRI Philips 1,5 T sekuen tersebut disebut sSh MRCPrad (single shot MRCP radial). Kemudian pada sekuen tersebut dilakukan aplikasi parallel acquisition technique atau pada pesawat MRI Philips 1,5 T disebut dengan sensitivity encoding (SENSE). Scanning dilakukan dengan dan tanpa aplikasi SENSE pada volunteer normal yang berjumlah 10 orang. Kedua hasil citra diamati dan dinilai oleh 2 orang responden (radiolog), kemudian hasil penilaian dirangkum dan dilakukan uji Cohen's Kappa untuk mengukur tinggat kesepakatan (degree of agreement) dari kedua responden dalam menilai kedua teknik tersebut.

Hasil uji Cohen's Kappa menunjukkan hasil pada sekuen 2D thick slab SSFSE sebesar 0,732 dan pada sekuen 2D thick slab SSFSE SENSE sebesar 0,688. Menurut Altman (1991), nilai koefisien kappa <0,2 menunjukkan tingkat kesepakatan buruk, nilai koefisien kappa antara 0,21 hingga 0,40 menunjukkan tingkat kesepatakan kurang dari sedang, nilai koefisien koefisien kapaa antara 0,41 hingga 0,60 menunjukkan tingkat kesepakatan sedang, nilai koefisien kappa antara 0,61 hingga 0,80 menunjukkan tingkat kesepakatan baik dan niai koefisien kappa antara 0,81 hingga 1 menunjukkan tingkat kesepakatan sangat baik. Berdasarkan 
teori Altman diatas hasil uji kappa yang diperoleh menunjukkan tingkat kesepakatan yang baik karena berada pada rentang 0,61 hingga 0,80 .

Perbedaan Informasi Anatomi Antara Sekuen 2D Thick Slab Single Shot Fast Spin Echo Dengan dan Tanpa Parallel Acquisition Technique Pada Pemeriksaan MRCP

Berdasarkan hasil Uji Wilcoxon keseluruhan citra dengan membandingkan nilai $p$-value secara keseluruhan antara sekuen 2D thick slab single shot fast spin echo (SSFSE) dengan dan tanpa parallel acquisition technoque (SENSE) menunjukkan ada perbedaan yang bermakna informasi anatomi antara kedua sekuen tersebut. Hal tersebut ditunjukkan dengan nilai $p$-value sebesar 0,000 dengan tingkat kepercayaan (confidence level) 95\%. Perbedaan tersebut diakibatkan karena adanya penurunan waktu akusisi setengah dari waktu mula-mula. Penurunan waktu akusisi tersebut dikarenakan pada saat aplikasi SENSE dengan faktor 2 terjadi penurunan TR dan ETL yang merupakan faktor yang mempengaruhi waktu akusisi.

Pada uji wilcoxon setiap kriteria anatomi diperoleh beberapa anatomi yang memiliki perbedaan dan tidak memiliki perbedaan. Dilihat dari hasil uji wilcoxon diperoleh anatomi right hepatic duct, common hepatic duct, cystic duct dan main pancreatic duct memiliki perbedaan yang bermakna. Sedangkan pada anatomi gall bladder, left hepatic duct dan common bile duct tidak memiliki perbedaan. Hal tersebut dapat disebabkan karena adanya perbedaan waktu akuisisi dan letak slab yang tidak seragam. Pada sekuen 2D thick slab SSFSE memiliki waktu akuisisi yang lebih panjang karena memiliki echo train lenght (ETL) dan repetition time (TR) yang lebih panjang dimana kedua hal tersebut mempengaruhi panjang waktu akusisi. Dengan waktu akusisi yang panjang maka akan membuat waktu tahan nafas akan semakin panjang. Hal tersebut dapat menyebabkan nafas yang tidak teratur dan pada saat scanning pasien tidak mematuhi aba-aba tahan nafas dengan benar. Sehingga organ yang dituju tidak berada pada slab yang sudah diatur.

Pernyataan tersebut didukung dengan teori Cosntable (1992), T2 decay selama periode readout SSFSE yang panjang akan menyebabkan atenuasi sesuai dari echo yang akan diperoleh pada sekuen ini yang menghasilkan image sharpness, demikian menghasilkan image blurring sepanjang phase encoding direction. Margolis (2004), pada saat parallel imaging diaplikasikan pada sekuen 2D thick slab SSFSE maka penurunan jumlah phase encoding step dapat menyebabkan penurunan echo train lenght (ETL), menghasilkan readout pendek dengan sedikit $\mathrm{T} 2$ related signal decay dan memperbaiki detail gambar dengan mengurangi image blur. Reduksi image blur dapat diartikan sebagai edge enhancment yang dapat memperbaiki gambaran pertengahan dan tepi duktus pancreatobiliary.

Menurut Glockner (2005), Parallel imaging diaplikasikan pada pemeriksaan cardiac dan body, dimana breath hold sering digunakan dan sering menjadi sumber keluhan pasien. Perbedaan akuisisi melebihi kemampuan pasien dan kenyamanan pasien dalam breath hold akan mempengaruhi kualitas citra. Keuntungan akusisi yang cepat dapat digunakan untuk tujuan lain seperti mengurangi waktu akusisi, peningkatan kecepatan dapat digunakan untuk memperbaiki spasial resolusi pada waktu yang sama dan mengurangi image blurring.

Waktu akusisi pada sekuen 2D thick slab SSFSE tanpa aplikasi SENSE memiliki waktu akuisi 72 detik yang dibagi menjadi 9 kali breath hold sehingga diperoleh 8 detik per breath hold. Sedangkan pada sekuen 2D thick slab SSFSE dengan aplikasi SENSE memiliki waktu akuisis 36 detik dibagi menjadi 9 kali breath hold sehingga diperoleh 4 detik per breath hold. Semakin singkat waktu breath hold maka akan menghasilkan citra yang lebih baik karena meminimalkan image blur akibat kegagalan breath hold. Dapat dilihat pada gambaran duktus antara kedua sekuen tersebut.

Perbedaan waktu tersebut disebabkan karena menggunakan teknik yang berbeda pada sekuen 2D thick slab SSFSE. Pada sekuen 2D thick slab SSFSE menggunakan turbo factor yang panjang sehingga baris $k$-space terisi dengan cepat, sedangkan pada sekuen 2D thick slab SSFSE dengan aplikasi sense terjadi penurunan jumlah phase encoding step yang dapat menyebabkan penurunan turbo factor. Penurunan turbo factor tersebut dapat mengakibatkan penurunan waktu akusisi. Proses akuisis data pada sekuen 2D thick slab single shot fast spin echo (SSFSE) tanpa aplikasi SENSE lebih panjang dibandingkan dengan aplikasi SENSE. Dengan menggunakan faktor reduksi sama dengan 2 maka waktu akuisisi akan menjadi lebih singkat menjadi setengah waktu semula.

Menurut Glockner (2005), bahwa teknik dasar pada waktu akusisi adalah sebanding dengan jumlah phase encoding line pada akuisisi Cartesian. Peningkatan jarak antara phase encoding line pada k-space oleh faktor R ketika mempertahankan spatial resolution untuk mengurangi waktu akuisisi pada faktor yang sama. Seperti contoh ketika $\mathrm{R}=2$, setiap phase encoding yang tampak atau hanya setengah dari k-space telah disampling. Sebagai hasil, waktu akuisisi berkurang oleh faktor 2. Morelli dkk (2011), bahwa dengan SENSE tidak hanya menggunakan turbo factor yang panjang tetapi juga memanfaatkan elemen pada multipel koil penerima phased array dan mengurangi baris phase encoding pada $K$ space sesuai dengan faktor $1 / \mathrm{R}$ dimana $\mathrm{R}$ adalah reduction factor atau jumlah elemen pada koil phased array yang digunakan, sehingga sampling tidak mengisi semua $K$-space menjadikan waktu akuisisi data menjadi berkurang dan menjadi lebih cepat sesuai dengan $\mathrm{R}$ yang digunakan.

Pada aplikasi SENSE, menghasilkan waktu akuisisi yang lebih singkat namun tidak mengurangi kualitas citra. Menurut AAPM (2015), metode parallel imaging atau SENSE pada 2D Fourier imaging dengan phased array coil menghasilkan reduksi phase encoding step dimana reduksi tersebut dapat mengurangi waktu akuisis tanpa mengurangi spatial resolution. Pernyataan tersebut dibuktikan dari hasil dari uji wilcoxon yang diperoleh peneliti bahwa tidak terdapat perbedaan yang bermakna antara sekuen 2D thick slab SSFSE tanpa aplikasi SENSE maupun dengan aplikasi SENSE. 
Sehingga dengan waktu yang lebih singkat namun kualitas citra yang dihasilkan tidak berkurang.

Informasi Antomi Yang Lebih Baik Sekuen 2D Thick Slab Single Shot Fast Spin Echo Dengan dan Tanpa Parallel Acquisition Technique Pada Pemeriksaan MRCP

Berdasarkan hasil mean rank yang diperoleh dari uji wilcoxon secara keseluruhan diperoleh hasil bahwa nilai mean rank pada sekuen 2D thick slab SSFSE sebesar 0,00 sedangkan pada sekuen 2D thick slab SSFSE dengan SENSE sebesar 14,50. Dari hasil tersebut mean rank pada sekuen 2D thick slab SSFSE dengan SENSE lebih tinggi dibandingkan sekuen 2D SSFSE tanpa SENSE, maka sekuen 2D thick slab SSFSE dengan SENSE menghasilkan informasi anatomi yang lebih baik dibandingkan dengan sekuen tanpa aplikasi SENSE.

Nilai mean rank dari hasil uji wilcoxon dari masingmasing anatomi meliputi anatomi gall bladder (2D thick slab SSFSE $=0,00$ dan 2D thick slab SSFSE SENSE = 2,50), right hepatic duct (2D thick slab SSFSE $=0,00$ dan 2D thick slab SSFSE SENSE = 2,00), left hepatic duct (2D thick slab SSFSE $=0,00$ dan 2D thick slab SSFSE SENSE $=2,50$ ), common bile duct (2D thick slab SSFSE $=0,00$ dan 2D thick slab SSFSE SENSE = 2,50), common hepatic duct (2D thick slab SSFSE $=0,00$ dan 2D thick slab SSFSE SENSE $=2,50)$, cystic duct (2D thick slab SSFSE $=0,00$ dan 2D thick slab SSFSE SENSE $=2,50)$, dan main pancreatic duct (2D thick slab SSFSE = 0,00 dan 2D thick slab SSFSE SENSE = 3,00).

Nilai mean rank dari hasil uji wilcoxon dari masingmasing anatomi menunjukkan bahwa sekuen 2D thick slab SSFSE dengan SENSE lebih tinggi dibandingkan dengan sekuen 2D thick slab SSFSE tanpa SENSE. Hal tersebut menunjukkan bahwa sekuen 2D thick slab SSFSE dengan SENSE menghasilkan kejelasan informasi pada masingmasing anatomi yang lebih baik dibandingkan dengan sekuen tanpa aplikasi SENSE.

Menurut Glockner (2005) bahwa breath hold sering digunakan dan sering menjadi sumber keluhan pasien. Perbedaan akuisisi melebihi kemampuan pasien dan kenyamanan pasien dalam breath hold sesuai dengan kapasitasnya akan mempengaruhi kualitas citra.

Perbedaan tersebut terjadi karena terdapat perbedaan waktu per breath hold yang cukup bermakna. Pada sekuen 2D thick slab SSFSE dengan SENSE memiliki waktu breath hold 4 detik sedangkan pada sekuen tanpa SENSE memiliki waktu breath hold yang lebih panjang yaitu 8 detik. Waktu breath hold yang panjang dapat menyebabkan pasien kurang patuh terhadap aba-aba yang diberikan karena kemampuan tahan nafas pasien yang tidak tahan lama dan nafas yang kurang teratur. Pernafasan pasien dapat dimonitor dari respiratory triger yang diletakkan pada diafargma pasien dan muncul grafik yang menunjukkan pernafasan pasien pada layar monitor. Dengan waktu breath hold yang panjang, pasien sering mencuri untuk ambil nafas sehingga dapat mengakibatkan blurring pada gambar.

Menurut Margolis (2004), pada saat parallel imaging diaplikasikan pada sekuen 2D thick slab SSFSE maka penurunan jumlah phase encoding step dapat menyebabkan penurunan echo train lenght (ETL), menghasilkan readout pendek dengan sedikit $\mathrm{T} 2$ related signal decay dan memperbaiki detail gambar dengan mengurangi image blur. Reduksi image blur dapat diartikan sebagai edge enhancment yang dapat memperbaiki gambaran pertengahan dan tepi duktus pancreatobiliary.

Berdasarkan hasil penelitian diatas, aplikasi SENSE dengan faktor reduksi 2 mengurangi waktu akuisisi menjadi setengah dari waktu awal sehingga dapat mengurangi dan mencegah terjadinya image blurring. Selain itu aplikasi SENSE tidak mengurangi spatial resolution pada citra sehingga kualitas citra tidak menurun seiring dengan berkurangnya waktu akuisisi. Pendapat ini diperkuat dengan teori AAPM (2015), metode parallel imaging atau SENSE pada 2D Fourier imaging dengan phased array coil menghasilkan reduksi phase encoding step dimana reduksi tersebut dapat mengurangi waktu akuisisi tanpa mengurangi resolusi citra. Menurut Ryan dkk (2005), bahwa teknik yang cepat memiliki keuntungan tidak hanya dari mengurangi adanya pergerakan, tetapi juga potensial untuk mengurangi waktu akuisisi. Teknik paralel imaging memiliki potensi tersebut yaitu dengan menggunakan sekuens yang cepat dengan penggunaan gradien yang dioptimalkan, sehingga potensial untuk mendapatkan pengurangan waktu akuisisi tanpa mengurangi efek yang signifikan pada kualitas citra diagnostik yang diperoleh.

\section{SIMPULAN}

Ada perbedaan bermakna antara informasi anatomi yang dihasilkan sekuen 2D thick slab SSFSE dibandingkan dengan informasi 2D thick slab SSFSE dengan aplikasi sense yang dapat dilihat dari $p$-value sebesar 0,000 ( $\mathrm{p}<0,05)$ dengan tingkat kepercayaan 95\%. Sekuen 2D thick slab SSFSE dengan SENSE lebih tinggi dibandingkan sekuen 2D SSFSE tanpa SENSE, maka sekuen 2D thick slab SSFSE dengan SENSE menghasilkan informasi anatomi yang lebih baik dibandingkan dengan sekuen 2D thick slab SSFSE tanpa aplikasi SENSE.

\section{DAFTAR PUSTAKA}

AAPM. 2015. Parallel Imaging in MRI : Technology, Application, and Quality Control, Report No 18. American Physic o Physicists in Medicine.

Constable, RT, Gore JC. 1992. The Loss of Small Objects in vaiable TE Imaging; implication for FSE, RARE, and EPI. Magnetic Resonance Imaging.

Glockner, James F, MD, PhD, Houchun H. Hu, BME, David W. Stanley, BS, Lisa Angelos, $\mathrm{PhD}$ dan Kevin King, PhD. 2005. Paralel Imaging : A User Guide. RSNA

Kenneth, M Vitellas, MD, dkk. 2000. MR Cholangiopancreatography of Bile and Pancreatic Duct Abnormalities with Emphasis on the Single Shot Fast Spin Echo Technique. Amerika : Radiology Society of North America.

Kurihara, Yasuki. 2002. Coil Sensitivity Encoding : Advantage and Disadvantage in Clinical Practice. American Roentgen Ray Society.

Leyendecker, John R, dkk. 2015. Practice Parameter For The Perfomance of Magnetic Resonance Imaging (MRI) of the Abdomen (Excluding the Liver). USA : Committee on Body Imaging. 
Mandarano, G, dkk. 2008. The diagnostic MRCP examination : overcoming technical challenges to ensure clinical succes. Australia : Division of Medical Radiations.

Manfredi, Ricardo, Roberto Pozzi Mucelli. 2013. Magnetic Resonance Cholangiopancreatography Biliary and Pancreatic Ducts. Italy : Springer.

Margolis DJ, Bammer R, Chow LC. 2004. Parallel Imaging of The Abdomen. Top Magnetic Resonance Imaging.

Morelli, John N, Val M. Runge, Fei Ai, Ulrike Attenberger, Lan Vu, Stuart H. Schmeets, Wolfgang R. Nitz dan John E. Kirsch. 2011. An Imagebased Approach to Understanding the Physics of MR Artifacts. radiographics.rsna.org

Ryan, M, Cunningham, P, Cantwll, C, Brennan, D dan Eustace, S. 2005. A comparison of fast MRI of hips with and without parallel imaging using SENSE. The British Journal of Radiology.ISugiyono, Eri Wibowo. 2004. Statistika untuk Penelitian dan Aplikasinya dengan SPSS 10.0 for Windows. Bandung : ALFABETA. 